\title{
NOVIM DESETLETJEM NAPROTI
}

\author{
Eva Mermolja, Anja Benko, Alenka Grželj, Nives Ličen (ur.)
}

\section{SOUSTVARJAMO DRUŽBO ZNANIA Zbornik ob 60-letnici Zveze ljudskih univerz Slovenije Ljubljana, Zveza ljudskih univerz Slovenije, 2019}

Minulo leto je bilo za ljudske univerze pri nas posebno - mnoge so praznovale visoko obletnico delovanja oziroma ustanovitve. Krovna organizacija, Zveza ljudskih univerz Slovenije (ZLUS), je praznovala 60 let, enako tudi nekatere ljudske univerze (LU), ki so bile ustanovljene leta 1959. V letu 2021 pa se načrtuje tudi slovesno zaznamovanje 100-letnice prvih ljudskih univerz v Celju in Mariboru. To je častitljiv jubilej tudi, če se ozremo po Evropi.

Ob tej priložnosti nastajajo različni projekti za zaznamovanje tega dosežka. Pred seboj imam do bralca prijazno knjigo Soustvarjamo družbo znanja: zbornik ob 60-letnici ljudskih univerz Slovenije. Slika pove mnogo več od besed, je vtis ob prvem listanju. Besede zlahka postanejo suhoparne, ko se strokovnjaki po več kot pol stoletja trajajočem razvoju in iskanjih ozirajo na prehojeno pot, a besede $\mathrm{v}$ zborniku nikakor niso take. Zbornik je opremljen z izvirnimi besedili, ki nas popeljejo od zgodovinskih začetkov, kot se jih spominja prof. dr. Ana Krajnc, prek različnih vlog ljudskih univerz skozi čas do udeležencev današnjih rešitev. Skozi razvoj ljudskih univerz v času se lahko sprehodimo tudi med dilemami, ki so stiskale in stiskajo te pomembne ustanove izobraževanja odraslih v obdobju neoliberalizma, ko se je skupnostno izobraževanje začelo kazati kot alternativa. Predstavniki posameznih ljudskih univerz v zborniku predstavijo vrsto poskusov, ki jih je kot odgovor na ta trenja razvila mreža širom po Sloveniji. Bralcu pade v oči pojav množice aktualnih tematik, kot so poti integracije, večnamenski romski centri, povezovanje izobraževanja in lokalnega gospodarstva, socialna aktivacija in druge. Zaključuje pa jih neke vrste triangulacija osebnih pogledov: predstavnice odločevalcev, direktorja osrednje institucije za izobraževanje odraslih v državi in udeleženca programov z osebno izobraževalno zgodbo mladega migranta.

Posebna vrednost tega zbornika je medgeneracijsko sodelovanje. Šele čas pa bo pokazal, kako pomembno vlogo v profesionalnem razvoju bodočih andragogov je imelo tesno srečanje z zgodovino LU skozi živo pripoved njihovih starejših kolegov, ki so delovali in 
delujejo v LU. Študentje so imeli namreč priložnost, da so v okviru pridobivanja raziskovalnih veščin neposredno sodelovali in pomagali soustvarjati predstavljeni zbornik.

(Pre)hiter tehnološki napredek prinaša vrsto vprašanj, ki še nimajo pravega odseva in odgovora v izobraževanju odraslih. Na primer: kakšna naj bo etična drža izobraževalca, ko ga bo udeleženec postavil pred vprašanja o genetskem inženiringu ali o usodnem spreminjanju človeških teles z nanobiotehnologijo. Ali kako naj se andragog praktično odziva na zahteve menedžerjev po skoraj popolni prilagoditvi programov usposabljanja v delovnih okoljih, ko je na preizkušnji dobrobit odraslega in zaveza, da delujemo v prid njegovemu opolnomočenju.

Okrogle obletnice so idealen čas za čestitke, razmislek, nove vizije in predvsem pogum. Naj ta ne usahne v novih desetletjih, ki so pred strokovno skupnostjo kot celoto.

Petra Javrh 